\title{
Developing a Long Passing Skill Measuring Instrument For Soccer School Student
}

\author{
1st Ardi Nusri \\ Sport Education Post-Graduate Program \\ Universitas Negeri Semarang \\ Semarang, Indonesia \\ ardi.nusri@yahoo.com
}

\begin{abstract}
This study aims to produce a long passing skill measuring instrument of soccer school student. This study applied research and development method by using experimental design with the steps; (a) draft development, (b) validation, (c) small group experiment, (d) large group experiment. The small group experiment is done three times, while the large group experiment consisting of 150 students from 8 soccer schools is only done once. Based on factorial analysis result (validity test) and test and re-test technique (reliability test), it is obtained that long passing skill measuring instrument is valid and reliable. The researcher develops a long passing skill measuring instrument for soccer school students in Medan.
\end{abstract}

Keywords — Long passing, measuring instrument Introduction

\section{INTRODUCTION}

In Indonesia, soccer becomes the most favorite sport for all ages, especially for children. Burgess and Gabbett (2013) stated that soccer can be considered as the most played sport in the world[4]. As proven in the World Championship held once per four years, it attracts more viewers rather than an Olympiad.

Conventionally, the majority of soccer players have been familiar with facts that soccer consists of four components; technique, tactics, physic, and mental (Danurwindo, et al., 2017:56)[6]. As Su'udi (2010:5) suggests that neither victory nor defeat is determined by inattention of one or two players, it indicates that soccer has to be played within a teamwork and good skill[23]. Individual skill is one thing to consider in a game. However, a good skill cannot be easily obtained as Su'udi (2010:6) claimed that individual skill of a great soccer player is obtained through a hard work, not an instinct way[23]. One of the skills that every player must have is long passing. Long passing can be very effective because defender players do not keep their rival much. Accuracy to do passing is essential since every single fault will be watched (DK, 2011:78).

Players' skill will increase gradually within coaching process, especially basic skill in doing long passing. In order to observe the improvement, it is necessary to do an evaluation of which also needs a measuring instrument to evaluate the practice result. Correspondingly, Purwanto (2014:1) revealed that a particular program has a certain goal and to know whether or not the program achieves the goal, it requires an evaluation[20]. Therefore, long passing skill taught to the students has to be evaluated. Decision making of evaluation is conducted based on the measurement result and the criteria (Purwanto, 2014:2)[20]. Skill in planning, doing a measurement activity and using information obtained from activity to make an accurate evaluation is necessary due to the success of the activity you choose. (Lacy, 2011:1).[17]

Previous studies on the written work of such topic have been conducted by some researcher. Vieira, Vitor, Rodrigo (2017) reviewed that five tests prove sensible construct validity that can be applied to predict accuracy (penalty kick, free kick, rolling ball kick, corner kick[24]. Cripps, Hopper, and Joyce (2015) showed that kicking skill and hand ball has a strong validity and reliability[5].

\section{A. Long Passing}

Knap, as cited in Ali (2011)[1], defined classic skill as skill to get results with high accuracy by energy expense and minimum time expense. The simplest skill in soccer is socalled as basic skills and one of those that a soccer player should have is long passing skill. A certain situation within soccer game sometimes asks players to give a ball to another player with further distance. Thus, it requires players to do long passing. Long passing is a technique that is rarely taught by coaches. Distance, accuracy, penetration, especially to the player who is ready to receive the ball and skill to change an attack point quickly and accurately are requirements in a modern game (Martin, 2011: 39)[19].

To do passing in the field with further distance, one has to bounce the ball by using shoes back part, not shoes inside part (Mielke, 2007:22). There are several things to consider to do long passing; (a) kick the ball at low position to carry more force, (b) tilt the body back when touching the ball, (c) firmly place the foot as a pedestal slightly in front of the ball with slightly sideways, (d) strecth out the hand to get the balance (Mielke, 2007: 22). Mistakes in doing a long passing accurately is still found and it has to be changed (DK, 2011: 79).

Ideally, students' skill at coaching program in a soccer school increase including the basic skill of long passing. A particular program has a certain goal and to know whether or not the program achieves the goal, it requires an evaluation (Purwanto, 2014:1)[20]. Skill in planning, doing a measurement activity and using information obtained from activity to make an accurate evaluation is necessary due to the success of the activity you choose. (Lacy, 2011:1)[17]

Evaluation is a systematic and sustainable process in collecting, describing, interpreting, and providing information about a certain program as a base to make desicions, to 
establish policies, and arrange following programs (Widoyoko, 2012:6)[26].

Evaluation and measurement are mutually and constantly interconnected. Evaluation is conducted once measurement is done and evaluation decision is carried out based on the measurement result (Purwanto, 2014:1)[20]. Lacy (2011:5) defined measurement as a technique needed to do an evaluation[17]. A measurement represents an attribute status or a certain property underlying a terminal process. Verduci in Widiastuti (2011:2) believed that measurement is beneficial for determining information about an object correctly[25]. A measurement must be correct, reliable, subjective and the result must be presented in numeric form denoting a number of property or attribute being measured (Lacy, 2011:4)[17].

According to Erlangga football trainer (2017:128)[9], once the seasonal training is over, it is significant to do assessment toward students' development on the guidance being taught. Furthermore, Widiastuti $(2011,5)$ asserted that measurements applied in sport or sport education are based on several notions: (1) goals which are supposed to be measured corresponding with the extent to which the goal are achieved, (2) scientific point of view that is closely related to sport development itself, (3) sport values cannot be found before measurement is conducted, (4) benefits or advantages to develop the program, (5) professionalism (trained and experienced)[25].

\section{B. The Principle of Measurement}

The are some principles which determine evaluation success according to Fenanlampir and Faruq (2009:9): (1) being aligned to the education philosophy, (2) being done based on the goal, (3) positioning testing as one of the parts of measurement and measurement as one of the parts of evaluation, (4) interpreting testing result in individual development context including physical, intelectual, emotional, social, and moral aspects comprehensively, (5) referencing to the notion that all one's attributes can be tested and measured. (6) discovering the early skill which is then compered to the test result. (7) using valid and reliable measuring instrument or test due to its influence toward the evaluation result[10].

A measurement which only aims to get data or informations is just wasting time, energy, and expense. The benefit and the use of measurement as stated by Lacy (2011:58 ) is for diagnosis, classification, presentation, repair, motivation, evaluation, program, human relationship, and forecast[17]. Widiastuti (2011:5-8) also affirmed that the use of test and measurement is to determine status, clarification, diagnosis, guidance, motivation, teaching development, teacher/coach assessment, method, and material[25].

A teacher or coach is required to choose a good measuring instrument to obtain a good coaching decision as well. Therefore, a measurement or test must fulfill particular conditions. There are five conditions of a good test proposed by Arikunto (2013:72); valid, reliable, objective, practical, and economical. While according to Purwanto (2014: 153) the conditions of a good learning outcome measurement are validity and reliability[20].

Once the data is obtained from a valid instrument, it can be assured that the instrument is valid because it provides a potrayal description about the data based on real situation as well (Arikunto, 2013: 73). Azwar (2016: 8)[2] suggested that validity is to what extent a test accuracy or scale in running its measuring function. A measuring instrument is not only able to reveal data as well but also to provide careful descriptions regarding to the data (Widiastuti, 2011: 9)[25].

Reliability is closely related to consistency, stability, and dependability (Usman and Setiyadi, 2009: 287). Reliability is a measurement set which has consistency when the measurement is conducted using the exist measuring instrument continously (Sugiyono, 2009: 137). Although reliability has some different terms, such as consistency, stability, and dependability, but the main idea underlying the concept of reliability is to what extent the measurement result can be trusted (Azwar, 2016:7)[2]

Based on the the principal, goal, benefit, and conditions of the measurement above, a coach has to conduct a test or measurement. By conducting a test or measurement, a coach can have accurate data to do an evaluation on his/her students. Thus, the evaluation or assessment result obtained can be a guidance or base to take a next step(s). The previous studies showed that coaches in soccer school in Medan do not have a sufficient evaluation instrument. The evaluation result is only taken from observation. Whereas, evaluation done only by observation is carries a lot of weaknesses, one of which is subjectivity. Nicholls and Worsfold (2016) reported that bad observation accuracy level from six elite coaches in doing evaluation toward ten young soccer players in eight competitions through observation brings a significant implication in talent identification assessment. This finding encourages the importance of performance analysis to provide an accurate and comprehensive additional back pass in a coaching process. Therefore, the researcher is interested to develop a long passing skill measurement model for soccer schools students aged 14-15.

\section{MATERIALS AND METHODS}

This research focused on the development of soccer skill measuring instrument for soccer school students. The method employed was research and development (RnD). Research and Development is a type of research used to produce a particular product and to test the effectiveness of the product itself (Sugiyono, 2014: 297). Procedures applied in this research were:

1. The preliminary study phase includes; (a) literature study (b) data analysis of preliminary study result and descriptions of field data finding, and (c) preparation of initial product design of measuring instrument to be developed.

2. The developmental stage; the draft was distributed to the experts to be corrected and subsequently revised. To gain the result of the revision draft, Focus Group Discussion (FGD) was conducted which involved the experts, the draft 
revised and the design of measuring instrument to be tested.

3. The phase of measuring instrument test; tests were conducted on several soccer schools by the experimental method. During the tests, the experts and the researcher took notes of both observations and evaluations. Then, the result was discussed and evaluated by the researcher, the trainers and the observers in which the draft got any corrections. The above steps are shown in Figure 1.
The Preliminary Study The development of measuring instrument
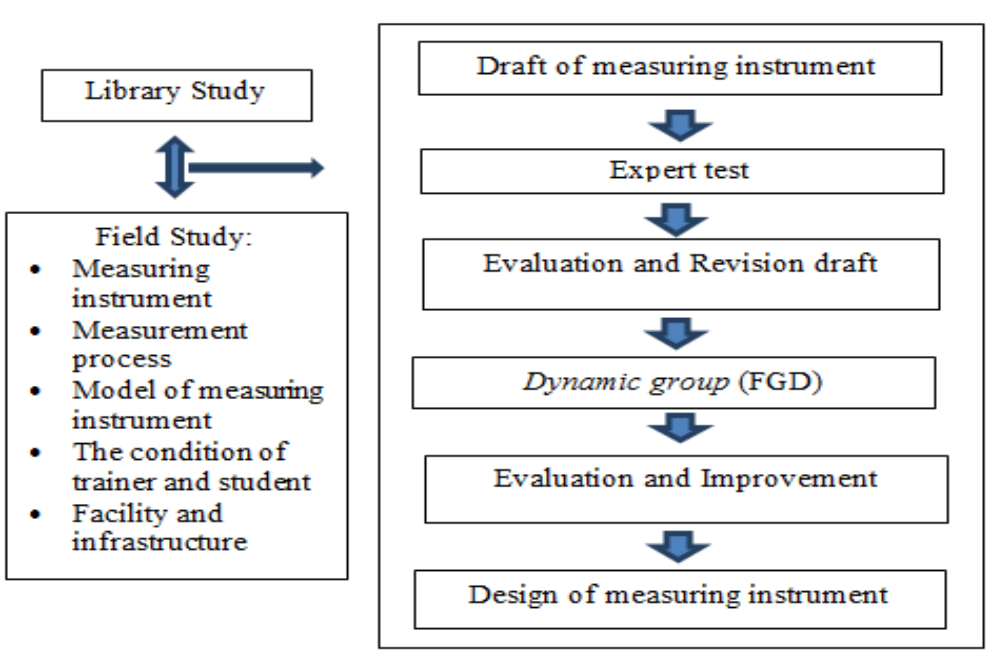

The test of measuring instrument

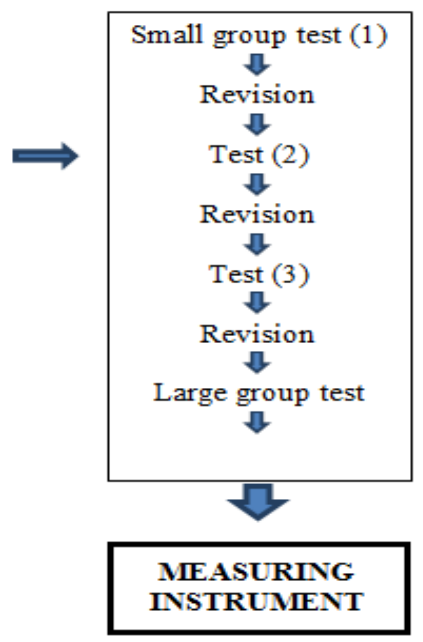

Fig.1. T he research framework for measuring instrument development.

After the draft was revised in accordance with the result of expert validation and FGD, measuring instrument was tested three times in small groups and a single test in a large group. The tests ran from January to September 2015. The first small group test involved 56 students, the second group were 12 students, while the third group belonged to 21 students. The revisions were made on the basis of data analysis, notes, and input of the experts and the trainers. The chronology can be seen in table 1 .

TABLE 1: THE CHRONOLOGY OF MEASURING INSTRUMENT

\begin{tabular}{|c|c|c|c|c|}
\hline \multirow{2}{*}{$\begin{array}{c}\text { Type of } \\
\text { test }\end{array}$} & \multicolumn{3}{|c|}{ Small Group Test } & Large Group \\
\cline { 2 - 4 } & Test I & Test II & Test III & Test \\
\hline Long & & & & \\
Passing & & & & \\
& & & & \\
\hline
\end{tabular}

Basically, the data used in this research was qualitative and quantitative data in which the qualitative data had been done since the beginning of the research activities and it went on and on until finished. Whereas, the quantitative data were collected through experiments in small and large samples that included on primary data. Besides, the subjects of this research were soccer school students of Medan City, namely Soccer School Gumarang, Soccer School Kenari, Soccer School Patriot, Soccer School Bhineka, Soccer School Bima, Soccer School Mandiri, Soccer School Putra Melati, Soccer School Perfect Unimed, and Soccer School Tasbi. Then, the tests were conducted on Saturday and Sunday and after that, the researcher did revisions. The revisions were based on the results of the data obtained, notes, the experts' advice, and the trainers. The similar activities were done continuously to get a measuring instrument that could describe the true skill of students who were tested.

The data obtained were tested its validity and reliability. To ensure the data were correct, the researcher used some threats to increase the persistence of the students. Likewise, Sugiyono (2015: 270) states that the validity test of data in qualitative research includes credibility test (internal validity), transferability (external validity), dependability (reliability), and confirmability (objectivity).

\section{RESULT AND DISCUSSIONS}

The result of preliminary study or field finding is described and analyzed in order to get a formulation of the data that has been collected. The formulation is a descriptive and analytical that refers to the purpose of the preliminary study. Then, the result of need analysis and field finding gained by the trainers toward the students are done only through the observation. In addition, the questionnaire given to both trainers and parents also obtain that the measuring instrument to assess the long passing skill of students is very needed. Based on this phenomenon, the researcher develops a model of measuring intrument for long passing skill for Soccer School students who were in 14-15 years old. The draft made is consulted to the experts.

The development of the instrument is designed in un interrupted repetition the students start the test from a 2 × 2 $\mathrm{m}$ square box and there are two instructions must be followed, they are 'ready and yes'. The first thing that the students do is standing in the square box, while the officer gives a signal 'yes' to start. Then, the student should kick the ball to the target 3 times, which the target area is divided 
into three parts (each part has score 3, 2, and 1). Besides, the scoring does not just come from the target area, but it also gain from the duration which is recorded in stopwatch. Thus, the students try to get a high score as fast as they can. A simple scheme of this test field is drawn in Figure 2.

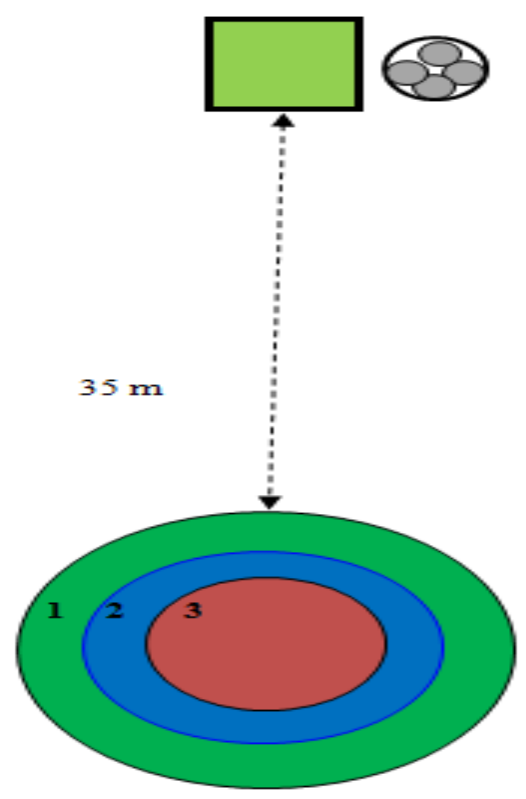

Fig. 2. Scheme Instrument

In addition, the draft designed is validated by 3 soccer experts, 2 A AFC licensed coaches, 1 soccer lecturer, 3 evaluation experts and 2 experts of test and measurement. The experts' record of the initial draft is (a) each test item must be completed with a description of the assessment, (b) the use of consistent terms, (c) the corrected editorial, (d) each test item should be timed (not only the total time), (e) consider the repetition of each test item.

\section{A. Result of Development Test}

The researcher tested the draft to both small group and large group. As a result, there were some occurrences during the testing process, namely (a) the target distance of long passing is too far, and (b) the target size of long passing is not ideal, as shown in table 2:

TABLE 2: THE DEVELOPMENT OF MEASURING INSTRUMENT

\begin{tabular}{|c|c|c|c|c|}
\hline \multirow{2}{*}{ Type of test } & \multicolumn{3}{|c|}{ Small Group Test } & \multirow{2}{*}{$\begin{array}{c}\text { Large } \\
\text { Group } \\
\text { Test }\end{array}$} \\
\hline & Test I & Test II & Test III & \\
\hline $\begin{array}{l}\text { Long } \\
\text { Passing }\end{array}$ & $\begin{array}{l}\text { - The target is too far } 35 \\
\mathrm{~m} \\
\text { - The target area of the } \\
\text { test is less proportional } \\
(1: 6 \mathrm{~m}, 2: 4.5 \mathrm{~m}, 3: 3 \\
\mathrm{m}) \\
\text { - Repetition is played } \\
\text { three times }\end{array}$ & $\begin{array}{l}\text { - The target is still far } \\
\text { away }(30 \mathrm{~m}) \\
\text { - The target area of the } \\
\text { test is proportional (1: } \\
6 \mathrm{~m}, 2: 4 \mathrm{~m}, 3: 2 \mathrm{~m}) \\
\text { - Repetition is reduced } \\
\text { from three times to two } \\
\text { times. }\end{array}$ & $\begin{array}{l}\text { - The target is } \\
\text { ideal ( } 25 \\
\text { m) }\end{array}$ & \\
\hline
\end{tabular}

The development of long passing skill must meet the validity and reliability test. The test results of validity and reliability are as follows:

TABLE 3: THE RESULT OF VALIDITY TEST

\begin{tabular}{|c|l|c|c|c|c|c|c|c|c|}
\hline \multirow{2}{*}{ No } & \multirow{2}{*}{ Component of Long Passing } & \multicolumn{7}{|c|}{ Test Phase } \\
\cline { 3 - 10 } & & \multicolumn{2}{|c|}{ Test l } & \multicolumn{2}{|c|}{ Test 2 } & \multicolumn{2}{|c|}{ Test 3 } & \multicolumn{2}{|c|}{ Large Sample } \\
\cline { 3 - 10 } & & $\mathrm{r}$ & Exp. & $\mathrm{R}$ & Exp. & $\mathrm{r}$ & Exp. & $\mathrm{r}$ & Exp. \\
\hline 1 & Pedestal position & 0,110 & $\mathrm{TV}$ & 0,664 & $\mathrm{~V}$ & 0,617 & $\mathrm{~V}$ & 0,969 & $\mathrm{~V}$ \\
\hline 2 & Viewpoint & 0,623 & $\mathrm{~V}$ & 0,623 & $\mathrm{~V}$ & 0,854 & $\mathrm{~V}$ & 0,930 & $\mathrm{~V}$ \\
\hline 3 & Kicking footposition & 0,352 & $\mathrm{~V}$ & 0,622 & $\mathrm{~V}$ & 0,790 & $\mathrm{~V}$ & 0,721 & $\mathrm{~V}$ \\
\hline 4 & Ball position & 0,415 & $\mathrm{~V}$ & 0,862 & $\mathrm{~V}$ & 0,577 & $\mathrm{~V}$ & 0,947 & $\mathrm{~V}$ \\
\hline 5 & Power & 0,650 & $\mathrm{~V}$ & 0,412 & $\mathrm{TV}$ & 0,820 & $\mathrm{~V}$ & 0,969 & $\mathrm{~V}$ \\
\hline 6 & Follow through & 0,215 & $\mathrm{TV}$ & 0,811 & $\mathrm{~V}$ & 0,832 & $\mathrm{~V}$ & 0,847 & $\mathrm{~V}$ \\
\hline
\end{tabular}

The data above shows that the 1 st test was an invalid long passing component that is foot position and follow through, so as it was performed and tested in the 2nd test. Later on, the 2nd test result exhibited that there was an invalid long passing component, namely power used to kick, then it was revised and tested on the 3rd occasion. While in the 3rd test evidenced that the overall data was valid and subsequently performed in a large sample. In the last sample test, it was valid which meant the validity of measuring instrument development had fulfilled the validity test.

\section{TABLE 4: THE RESULT OF THE RELIABILITY TEST}

\begin{tabular}{|c|c|c|c|c|}
\hline No & Test & Category & Reliability score & Criterion \\
\hline \multirow[t]{2}{*}{1} & \multirow[t]{2}{*}{ Test 1} & Score & 0,460 & Unreliable \\
\hline & & Time & 0,481 & Unreliable \\
\hline \multirow[t]{2}{*}{2} & \multirow[t]{2}{*}{ Test 2} & Score & 0,610 & Reliable \\
\hline & & Time & 0,674 & Reliable \\
\hline \multirow[t]{2}{*}{3} & \multirow[t]{2}{*}{ Test 3} & Score & 0,905 & Reliable \\
\hline & & Time & 0,714 & Reliable \\
\hline \multirow[t]{2}{*}{4} & \multirow[t]{2}{*}{ Large sample test } & Score & 0,781 & Reliable \\
\hline & & Time & 0,836 & Reliable \\
\hline
\end{tabular}

The result table shows that in the first test of the score and period is not reliable, so the measuring instrument is repaired and tested in the 2 nd session. Afterward, the 2 nd test shows that the score and time categories are declared reliable. Even, it has reliability, the development of measuring instrument does not stop in the 2nd test, because it still has invalid long passing component. So as either the improvement or the experiment in the 3rd test are conducted. Surprisingly, the reliable data from both score and time has required the reliability test. Furthermore, the measuring instrument is tested in a large sample and the result shows that the instrument is valid (V) and reliable. Thus, it can be stated that the development of measuring instrument can be used to measure long passing skill in soccer. 
The final result of this scoring field scheme which obtains satisfactory result changes from the initial schema. The transformation is described in the following table.

TABLE 4: CHANGES INSTRUMENT BETWEEN INITIAL AND FINAL DESIGN

\begin{tabular}{|l|l|}
\hline Initial Development & Final Development \\
\hline Long passing distance $35 \mathrm{~m}$ & $\begin{array}{l}\text { The long passing distance } \\
\text { of } 25 \mathrm{~m}\end{array}$ \\
\hline 3 times repetitions & Twice repetitions \\
\hline $\begin{array}{l}\text { The radius of a long passing } \\
\text { target circle is } 3 \mathrm{~m} \text { for score } \\
3,4, \text { but } 5 \mathrm{~m} \text { for score } 2, \\
\text { and } 6 \mathrm{~m} \text { for score } 1 .\end{array}$ & $\begin{array}{l}\text { passing target circle is } 2 \mathrm{~m} \\
\text { for score } 3,4 \mathrm{~m} \text { for score } 2, \\
\text { and } 6 \mathrm{~m} \text { for score } 1 .\end{array}$ \\
\hline
\end{tabular}

\section{B. Discussion}

Based on the statistical calculations mentioned before, it is proven that the long passing skill instrument developed is valid and reliable. It is in accordance with the theory that students who have the accurate long passing ability will get high scores and shorter duration. Simirlarly, Cripps, Hopper, and Joyce (2015) by the title Inter-Rater Reliability and Validity of The Australian Football League's Kicking and Handball Tests reports that kicking and handball skills have strong validity and reliability[5]. Zago, et.al (2014) states that skilled players take less time in completing tests because they are able to control the ball while running through shorter paths[27]. Russell, Benton, and Kingsley (2010) in their research entitled Reliability and Construct Validity of Soccer Skills Tests That Measure Passing, Shooting, and Dribbling report that shooting measurements are valid and reliable in measuring football skills[21].Thus, the long passing skill of Soccer School students generated in this study can be proven and it has good validity and reliability in measuring the skill of Soccer School students.

\section{CONCLUSION}

Based on the experiment test conducted in both the small groups and the large group, it can be drawn a conclusion that the long passing skill measuring instrument for Soccer School students in Medan is valid and reliable. Hence, the required instrument is able to be applied in soccer activity for measuring students' long passing skill that is beneficial for evaluation process.

\section{ACKNOWLEDGMENT}

The researcher would like to give lots of gratitude to Sports Education Study Program of Semarang State University which is pleased to receive the author to study at this institution and so does Medan State University who has given permission to the researcher's career. Besides, the depth thanks are also conveyed to Prof.'s promoter team; Dr. Hari Setijono, M. Pd., Prof. Tandiyo Rahayu, M. Pd., and Prof. Soegiyanto, KS., MS. for the attention, the encouragement, and the guidance is given. Furthermore, the same expression is also given to my comrades in arms who are willing to assist in all matters.

\section{REFERENCES}

[1] Ali, A. 2011. Measuring Soccer Skill Performance: A Review. Scandinavian Journal of Medicine and Science in Sports, 1-13 doi: 10.1111/j.1600-0838.2010.01256.x. Auckland New Zealand.

[2] Azwar, S. 2016."Reliability and validity," IEEE. Transl. Realibitas dan Validitas. Yogyakarta: Pustaka Pelajar.

[3] Avry, Y., etc Grassroots. no year. Zurich: FIFA Education and Technical Development Departement.K. Elissa, "Title of paper if known," unpublished.

[4] Burgess, D.J., and Gabbett, T.J. 2013. Physiological Test for Elite Athletes. Edition 6th. Lower Mitcham South Australia: Human Kinetics.

[5] Cripps, A.J., Hopper, L.S., and Joyce, C. 2015. InterRater Reliability, and Validity of The Australian Football League's Kicking and Handball Tests. Fremantle Australia. Journal of Sports Science and Medicine, 14 675-680.

[6] Danurwindo, Putera, G., Siddik, B., Prahara, J L. 2017. "Curriculume Football Training Indonesia", IEEE Transl. Kurikulum Pembinaan Sepakbola Indonesia. Jakarta: High Performance Unit PSSI.

[7] Darmawan, R. dan Putra, G. 2012. "Be Winner With Football Possesion", IEEE Transl. Jadi Juara Dengan Sepak Bola Possesion. Jakarta: KickOff Media-RD Books.

[8] Essential soccer skills key tips and techniques to improve your game. (2011). London: DK Publishing.

[9] Erlangga Football Trainers. 2017. "Guidance of Childrean Football Training", IEEE Transl. Panduan Kepelatihan Sepakbola Anak. Jakarta: Erlangga.

[10] Fenanlampir, A. dan Faruq, M.M. 2015. "Tesr and Measurements in Sports", IEEE Transi. Tes dan Pengukuran Dalam Olahraga. Yogyakarta: Penerbit CV. Andi Offset.

[11] FIFA (tanpa tahun). Education \& Technical Development Departement. Small Sided Games and Integrating Physical Preparation. FIFA. RVA Druck und Medien Alstatten: Zurich Switzerland.

[12] Garland, J. 2014. Youth Soceer Drills. Third Edition. Champaign: Human Kinetics.

[13] Huijgen, B. C. H., Elferink-Gemser, M. T., Ali, A., Visscher, C. 2013. Soccer Skill Development in Talented Players. Groningen: University of Groningen. International Journal of Sports Medicine. 86. Epub Ahead of Print.

[14] Kemendiknas 2016. "General guidance of Indonesian Spelling. Edition IV", IEEE Transl. Pedoman Umum Ejaan Bahasa Indonesia. Edisi IV. Jakarta: Badan Pengembangan dan Pembinaan Bahasa.

[15] Koger, R. 2007. "Basic Training Football Training for Teenager,, IEEE Transl. Latihan Dasar Andal Sepakbola Remaja. Terjemahan Subiyanto, A. Klaten: SMK.

[16] Koger, R. 2009. The Baffled Parent's Guide to Fix - It Drills for Youth Soccer. New York: Mc Graw Hill.

[17] Lacy, A.C. 2011. Measurement \& Evaluation in Physical Education and Exercise Science. 6th Edition. Boston : Pearson Education Inc.

[18] LA84 Foundation. 2008. LA84 Foundation Soccer Coaching Manual. Los Angeles: LA84 Foundation). 
[19] Martin, J. 2012. Techniques + Tactics. Auckland: Meyer \& Meyer Sport (UK) Ltd.

[20] Purwanto 2014. "Evaluation of Study Result", IEEE Transl. Evaluasi Hasil Belajar. Yogyakarta: Pustaka Pelajar.

[21] Russel, M., Benton, D, Kingsley, M. 2010. Reliability and Construct Validity of Soccer Skills Tests That Measure Passing, Shooting, and Dribbling. Journal Sporst Science. Nov: 28(13):1399-408.

[22] Schreiner, P. 2010. Perfect Ball Control Soccer. 2nd. Edition. Auckland: Meyer and Meyer (UK) Ltd.

[23] Su'udi, A. 2010. Football Inspirations For Success. Meraih Sukses Dengan Filosopi Sepakbola. Jakarta: PT. Gramedia Pustaka Utama.

[24] Vieira, L.H., Vitor, A., Rodrigo, A. 2017. Construct Validity of Tests That Measure Kick Performance for
Young Soccer Players Based on Cluster Analysis: Exploring The Relationship Between Coaches Rating and Actusl Measures. The Journal of Sports Medicine and Physical Fitness, Vol. 57, No. ?, 1-10, doi: 10.23736/S0022-4707. 16.06863-8.

[25] Widiastuti 2011. "Test and Measuruement of Sport",IEEE Transl. Tes dan Pengukuran Olahraga. Jakarta: PT. Bumi Timur Jaya.

[26] Widoyoko, E.P. 2017. "Evaluation Training Program" IEEE Transl. Evaluasi Program Pelatihan. Yogyakarta: Pustaka Pelajar.

[27] Zago, M., Piovan, A.G., Ciprandi, D., Lovecchio, N., Giuriola, M., Ferrario, V.F. 2014. Dribbling Skill Determinants in Youth Soccer Players. Italian Journal of Anatomy and Embryology, Vol. 119, N. 1 (Supplement): 199. 